\title{
MEK inhibition appears to improve symptom control in primary NRAS-driven CNS melanoma in children
}

\author{
Veronica A Kinsler ${ }^{\star}, 1,2$, Patricia O'Hare ${ }^{3}$, Thomas Jacques ${ }^{4}$, Darren Hargrave ${ }^{3,5}$ and Olga Slater ${ }^{3}$ \\ ${ }^{1}$ Paediatric Dermatology, Great Ormond Street Hospital for Children NHS Foundation Trust, London WC1N 3JH, UK; ${ }^{2}$ Genetics \\ and Genomic Medicine, UCL Institute of Child Health, 30 Guilford Street, London WC1N 1EH, UK; ${ }^{3}$ Paediatric Oncology, Great

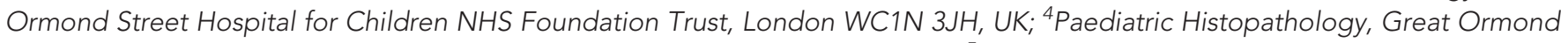 \\ Street Hospital for Children NHS Foundation Trust, London WC1N 3JH, UK and ${ }^{5}$ Developmental Biology and Cancer Programme, \\ UCL Institute of Child Health, 30 Guilford Street, London WC1N 1EH, UK
}

Background: Primary melanoma of the CNS in children is extremely rare, and usually linked to congenital melanocytic naevus syndrome, caused by mosaicism for oncogenic NRAS mutations. Outcome is fatal in all cases. Data from murine and in vitro studies suggest that MEK inhibition is a possible therapeutic option.

Methods: Four children with NRAS-mutated CNS melanoma were treated with Trametinib on a compassionate basis.

Results: All four had an improvement in symptoms and objectively in signs. These varied from mild improvement for 1 month, to a sustained symptom-free period of 9 months in one case. In all cases there was eventual disease progression through treatment, followed by rapid death after discontinuation. There were no clinically-significant side effects.

Conclusions: Trametinib is the first therapy to show any objective or measurable effect in NRAS-mutated primary CNS melanoma, with few side effects in this small series. The role of this therapy should be explored further in this rare paediatric tumour.

Primary CNS melanoma in childhood is extremely rare (CRUK, 2016), usually but not exclusively arising in the context of congenital melanocytic naevus (CMN) syndrome (unpublished data from our tertiary referral paediatric oncology department). $\mathrm{CMN}$ syndrome is the association of congenital moles with extracutaneous features such as congenital neurological malformations (Kadonaga et al, 1992; Barkovich et al, 1994; Acosta et al, 2005; Kinsler et al, 2008) and characteristic facies (Kinsler et al, 2012) (Figure 1). The term CMN syndrome therefore incorporates the term Neurocutaneous Melanosis, which is one particular phenotypic subset of the extra-cutaneous associations of CMN. In postnatal life affected individuals are at increased risk of cutaneous and CNS melanoma, with the peak incidence in childhood (Krengel et al, 2006; Kinsler et al, 2017a). However, the majority of congenital cutaneous and neurological abnormalities do not lead to melanoma, even when neurological disease is symptomatic, and a new classification of congenital neurological findings has been able to identify high risk groups for all clinical outcomes including all-site melanoma (Waelchli et al, 2015; Kinsler et al, 2017a).

This syndrome is caused in $80 \%$ of cases by post-zygotic mosaicism for oncogenic mutations in codon 61 of NRAS (Kinsler et al, 2013), or in other words that a single mutated cell in the embryo leads to all the cutaneous and other congenital malformations, and predisposes to malignancy by acting as a first hit in a multi-step process. Evidence for further mutation at the NRAS locus leading from the congenital to the malignant state has been demonstrated in a small number of cases, with loss of heterozygosity of the normal allele (Kinsler et al, 2013) or amplification of the mutant allele both described (Salgado et al, 2015). Copy-number abnormalities are also a very consistent finding in melanoma in this condition, and the specific number/ pattern of multiple large gains and losses helps distinguish

${ }^{\star}$ Correspondence: Dr VA Kinsler; E-mail: v.kinsler@ucl.ac.uk 

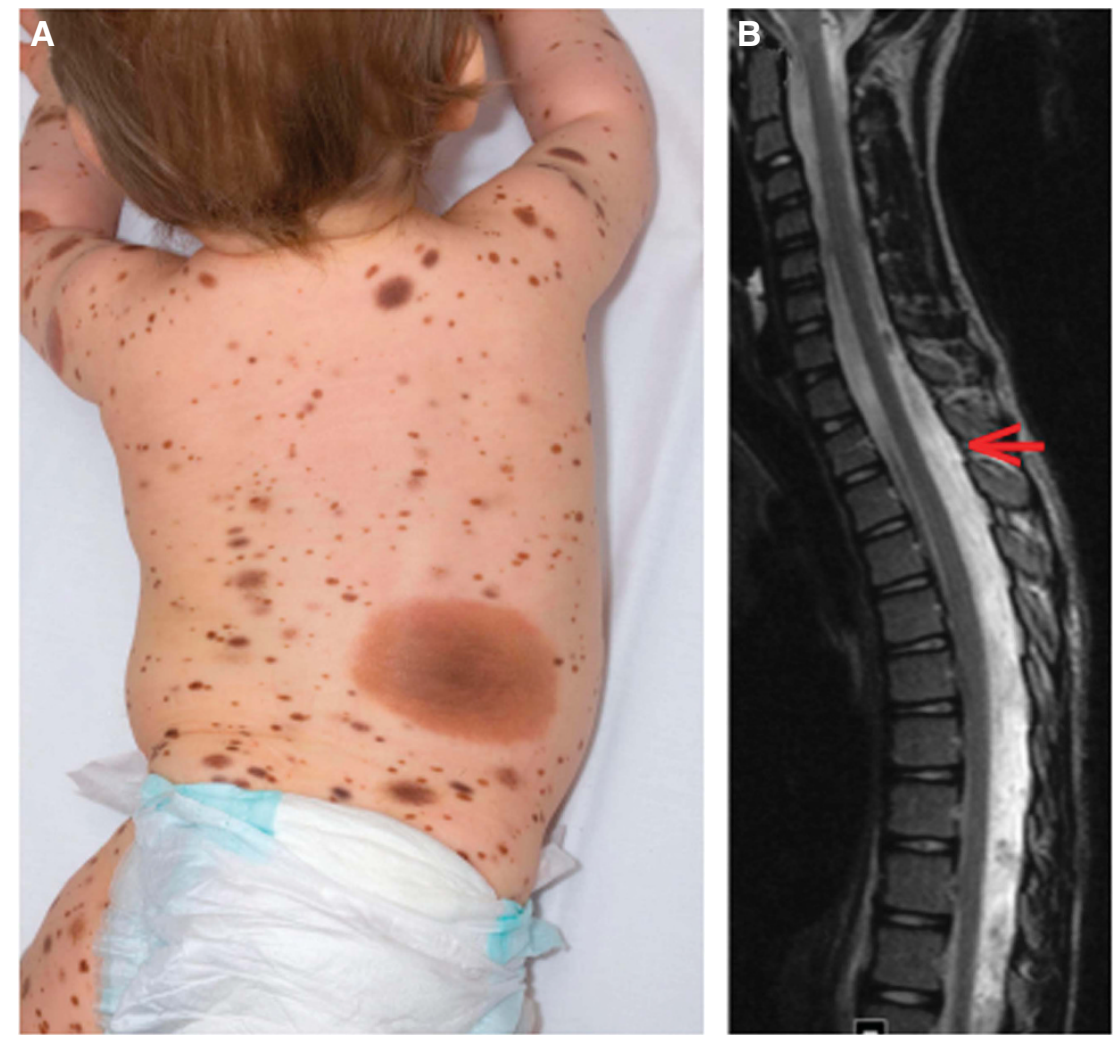

Figure 1. Examples of phenotype in congenital melanocytic naevus syndrome. Written consent was obtained for clinical photo publication. (A) Example of severe cutaneous phenotype. (B) Diffuse melanotic leptomeningeal disease—this requires biopsy and both histological and genetic testing before malignancy can be established, and should be viewed in the context of the baseline screening MRI of the CNS under 1 year. This case was leptomeningeal melanoma.

malignant from benign proliferations within the skin (Bastian et al, 2003), and also the CNS (Kinsler et al, 2017b).

Currently, the outlook for primary CNS melanoma in children is extremely bleak, with a recent review of our prospective in-house cohort (including these 4 cases) demonstrating 100\% mortality within 9 months of diagnosis (Kinsler et al, 2017a), comparable to the data from a retrospective literature review (Neuhold et al, 2015). Our experience of systemic therapies for this disease include Dacarbazine and Temozolomide, a single experience with antiCTLA-4 antibody therapy (Ipilimumab), and use of the mTOR inhibitor Sirolimus in three patients, none of which have had any measurable effect on symptoms or disease progression (unpublished data and Kinsler et al, 2017a). Due to driver NRAS mutations the use of selective BRAF inhibitors is contraindicated, whereas targeting the more distal MAPK pathway is a possible option. Data from a mouse model of NRAS codon 61 mosaicism have demonstrated inhibition of leptomeningeal disease with administration of a MEK inhibitor (Pawlikowski et al, 2015), with supporting evidence of the critical role of NRAS from a further murine model (Pedersen et al, 2013). One previous report of use in a single paediatric case was of limited use as the drug was started only days before death, although functional work in vitro was again supportive (Kusters-Vandevelde et al, 2014). These data encouraged us to test Trametinib in a small series of patients with this rare malignancy.

\section{MATERIALS AND METHODS}

We therefore obtained access to the MEK inhibitor Trametinib for four children on a compassionate basis from Glaxo SmithKline (Middlesex, UK) (patient phenotypic details in Table 1).
Trametinib was used initially at a dose of $0.0125 \mathrm{mg} \mathrm{kg}^{-1}$ per day in two patients (patients 1 and 2, Table 1); however, although both had symptomatic benefit (reversal of neurological signs) this was of short duration prior to rapid disease progression. When a higher dose of $0.025 \mathrm{mg} \mathrm{kg}^{-1}$ per day was established to be safe in ongoing phase I paediatric studies (GlaxoSmithKline, 2016) we increased the dose to this level in two further patients (patients 3 and 4, Table 1). Prior to starting Trametinib all patients had echocardiogram, ECG, ophthalmological exam and blood tests for full blood count, urea and electrolytes, liver function tests, gamma GT and creatinine kinase.

\section{RESULTS}

In all four patients we saw an objective improvement in symptoms and signs. In patient 1 this was limited to recovery of a small amount of movement in both upper limbs, from day 21 after starting treatment, and after these had been paralysed for approximately 2 months prior. This limited improvement was sustained for 4 weeks, before rapid worsening in neurological status related to intracerebral haemorrhage into the intraparenchymal tumour mass. Trametinib was stopped after 49 days of therapy and she died 10 days later.

In patient 2 , his parents reported a very rapid improvement in the child's mood, seeming much happier and less irritable within a few days of starting treatment. His seizures stopped, having been an ongoing problem for 3 months, and he was slowly weaned off his anti-seizure medication and oral steroids. In addition, he objectively regained power in his upper and lower limbs, as assessed by neurological examination. This improvement was sustained for 7 weeks before he suddenly decompensated, 
Table 1. Phenotype, genotype, response and outcome of patients with primary CNS melanoma treated with Trametinib, in order of commencing treatment

\begin{tabular}{|c|c|c|c|c|c|c|c|c|c|c|}
\hline $\begin{array}{l}\text { Patient } \\
\text { number }\end{array}$ & Sex & $\begin{array}{l}\text { Age at } \\
\text { diagnosis } \\
\text { of } \\
\text { melanoma }\end{array}$ & Outcome & $\begin{array}{l}\text { Skin disease } \\
\text { classification } \\
\text { (Krengel } \\
\text { et al, 2013) }\end{array}$ & $\begin{array}{l}\text { Screening } \\
\text { MRI CNS } \\
\text { under } 1 \text { year }\end{array}$ & $\begin{array}{l}\text { Primary } \\
\text { melanoma } \\
\text { site }\end{array}$ & $\begin{array}{l}\text { Leptomeningeal } \\
\text { tissue NRAS } \\
\text { genotype }\end{array}$ & $\begin{array}{l}\text { Initial and } \\
\text { final } \\
\text { Trametinib } \\
\text { doses }\end{array}$ & $\begin{array}{l}\text { Temporary } \\
\text { response }\end{array}$ & $\begin{array}{l}\text { Side } \\
\text { effects } \\
\text { requiring } \\
\text { treatment }\end{array}$ \\
\hline 1 & Female & $1.8 y$ & $\begin{array}{l}\text { Death age } \\
2.2 y\end{array}$ & $\begin{array}{l}\text { Multiple CMN, } \\
\text { no clearly larger } \\
\text { naevus, total } \\
>400 \text { naevi all } \\
\text { over body and } \\
\text { head, no nodules } \\
\text { Concensus } \\
\text { classification: S3, } \\
\text { C1, R0, NO, H1 }\end{array}$ & \begin{tabular}{l|} 
Complex \\
congenital \\
neurological \\
disease
\end{tabular} & $\begin{array}{l}\text { CNS, diffuse } \\
\text { leptomeningeal } \\
\text { melanoma, } \\
\text { infiltration of the } \\
\text { underlying } \\
\text { parenchyma, VP } \\
\text { shunt required }\end{array}$ & c. $181 \mathrm{C}>\mathrm{A} ; \mathrm{p} . \mathrm{Q} 61 \mathrm{~K}$ & $\begin{array}{l}0.0125 \mathrm{mg} \mathrm{kg}^{-1} \\
\text { per day }\end{array}$ & \begin{tabular}{l|} 
Limited \\
improvement \\
in upper limb \\
movement
\end{tabular} & $\begin{array}{l}\text { None. } \\
\text { Temporary } \\
\text { grade } 1 \text { rise } \\
\text { in creatine } \\
\text { kinase }\end{array}$ \\
\hline 2 & Male & $4.0 y$ & $\begin{array}{l}\text { Death, age } \\
4.6 y\end{array}$ & $\begin{array}{l}\text { Multiple CMN, } \\
\text { largest in cape } \\
\text { distribution, non- } \\
\text { circumferential, } \\
\text { projected adult } \\
\text { size } 20-40 \mathrm{~cm} \text {, } \\
\text { total } 100-200 \\
\text { naevi, } \\
\text { Concensus } \\
\text { classification } \\
\text { L1, S3, Trunk, } \\
\text { CO, RO, NO, H1 }\end{array}$ & $\begin{array}{l}\text { Complex } \\
\text { congenital } \\
\text { neurological } \\
\text { disease }\end{array}$ & $\begin{array}{l}\text { CNS, diffuse } \\
\text { leptomeningeal } \\
\text { melanoma, VP } \\
\text { shunt required }\end{array}$ & c. $181 \mathrm{C}>\mathrm{A} ;$ p.Q61K & $\begin{array}{l}0.0125 \mathrm{mg} \mathrm{kg}^{-1} \\
\text { per day }\end{array}$ & $\begin{array}{l}\text { Decreased } \\
\text { irritability, } \\
\text { cessation of } \\
\text { seizures, } \\
\text { improvement } \\
\text { in limb function }\end{array}$ & None \\
\hline 3 & Male & $1.5 y$ & $\begin{array}{l}\text { Death age } \\
2.3 y\end{array}$ & $\begin{array}{l}\text { Multiple CMN, } \\
\text { largest } \\
\text { circumferential } \\
\text { bathing trunk } \\
\text { distribution, } \\
\text { projected adult } \\
\text { size }>60 \mathrm{~cm} \text {, } \\
\text { total } 50-100 \\
\text { naevi, Concensus } \\
\text { classification: G2, } \\
\text { S3, Trunk, CO, R1, } \\
\text { NO, H2 }\end{array}$ & $\begin{array}{l}\text { Complex } \\
\text { congenital } \\
\text { neurological } \\
\text { disease }\end{array}$ & $\begin{array}{l}\text { CNS, diffuse } \\
\text { leptomeningeal } \\
\text { melanoma, VP } \\
\text { required. }\end{array}$ & c.181C>A; p.Q61K & $\begin{array}{l}0.0125- \\
0.025 \mathrm{mg} \mathrm{kg}^{-1} \\
\text { per day }\end{array}$ & $\begin{array}{l}\text { Cessation of } \\
\text { symptoms of } \\
\text { raised } \\
\text { intracranial } \\
\text { pressure, } \\
\text { stabilisation of } \\
\text { MRI findings }\end{array}$ & $\begin{array}{l}\text { None. } \\
\text { Temporary } \\
\text { grade } 1 \\
\text { increase in } \\
\text { creatine } \\
\text { kinase }\end{array}$ \\
\hline 4 & Female & $0.9 y$ & $\begin{array}{l}\text { Death age } \\
1.5 y\end{array}$ & No skin lesions & Not done & $\begin{array}{l}\text { CNS, diffuse } \\
\text { leptomeningeal } \\
\text { melanoma, } \\
\text { infiltration of } \\
\text { underlying } \\
\text { parenchyma, VP } \\
\text { shunt required }\end{array}$ & c. $181 \mathrm{C}>\mathrm{A} ;$ p.Q61K & $\begin{array}{l}0.0125- \\
0.025 \mathrm{mg} \mathrm{kg}^{-1} \\
\text { per day }\end{array}$ & $\begin{array}{l}\text { Cessation of } \\
\text { symptoms of } \\
\text { spinal cord } \\
\text { compression } \\
\text { and raised } \\
\text { intracranial } \\
\text { pressure }\end{array}$ & None \\
\hline
\end{tabular}

presenting with status epilepticus, and evidence of disease progression on MRI. Trametinib was stopped on day 54 of therapy and he died 3 weeks later from cord compression.

In patient 3 , the drug was started much earlier in the disease, when symptoms were intermittent acutely raised intracranial pressure without other focal neurological signs. After 56 days of therapy he had not had any further episodes of raised intracranial pressure, and a reassessment MRI of the brain and spine with contrast reported stable leptomeningeal disease with improvement in the drainage of the lateral ventricles, and a further MRI at 139 days still showed stable disease. Based on previous patient disease course these findings are very encouraging. This patient then proceeded to have an entirely symptom-free period for a total of 9 months on Trametinib during which he continued to have normal neurodevelopment. This was once again, however, followed by sudden clinical and radiological disease progression, and death from spinal cord compression three weeks after stopping Trametinib.

In patient 4, there was no skin involvement, but the leptomeningeal melanoma was indistinguishable from the other cases. This has rarely been reported in the literature, and could correspond to the same post-zygotic mutation affecting only the neurological system (Dechaphunkul et al, 2011; Sutton et al, 2011; Marana Perez et al, 2016; Szathmari et al, 2016). In this patient there was marked reversal of pre-terminal cord compression one week after the increase in dose of Trametinib, and a day after starting Dexamethasone; however, the latter has not previously had a sustained effect in our patients. The patient had been admitted to a hospice in a moribund state but became suddenly asymptomatic and was discharged home, and was then symptom-free for two months before rapid disease progression, and death within a week of stopping Trametinib.

Importantly, thus far, side effects have been very few and not clinically relevant (Table 1) in any patient.

\section{DISCUSSION}

Trametinib (MEK inhibition) is the first medical therapy to have had any observable effect in primary NRAS-driven CNS melanoma in children in our cohort. Furthermore, it appears to have markedly improved disease symptoms in some cases compared to the usual course we have seen in our cohort, allowing improved quality of life for affected children in their own homes, with no clinically-significant side effects in these first four cases. The failure to stop disease progression altogether is likely to be due to the additional mutations seen in the melanoma over and above the NRAS driver mutation. Although the disease has eventually progressed through treatment this is an important new first step in finding therapy for this condition. 


\section{ACKNOWLEDGEMENTS}

VK is funded by the Wellcome Trust, Award number WT104076MA, and the work was supported by Caring Matters Now Charity and patient support group, and by the National Institute for Health Research Biomedical Research Centre at Great Ormond Street Hospital for Children NHS Foundation Trust and University College London.

\section{CONFLICT OF INTEREST}

$\mathrm{DH}$ has acted as an unpaid advisor for Novartis. The remaining authors declare no conflict of interest.

\section{REFERENCES}

Acosta Jr. FL, Binder DK, Barkovich AJ, Frieden IJ, Gupta N (2005) Neurocutaneous melanosis presenting with hydrocephalus. Case report and review of the literature. J Neurosurg 102(1 Suppl): 96-100.

Barkovich AJ, Frieden IJ, Williams ML (1994) MR of neurocutaneous melanosis. AJNR Am J Neuroradiol 15(5): 859-867.

Bastian BC, Olshen AB, LeBoit PE, Pinkel D (2003) Classifying melanocytic tumors based on DNA copy number changes. Am J Pathol 163(5): $1765-1770$.

CRUK (2016) Cancer Research UK statistics. Available at: http:// www.cancerresearchuk.org/health-professional/cancer-statistics.

Dechaphunkul A, Kayasut K, Oearsakul T, Koonlaboon K, Sunpaweravong P (2011) Common presentation in an uncommon disease: case report of a patient with primary diffuse leptomeningeal melanocytosis. J Clin Oncol 29(33): e816-e818.

GlaxoSmithKline (2016) Study to investigate safety, pharmacokinetic (PK), pharmacodynamic (PD) and clinical activity of trametinib in subjects with cancer or plexiform neurofibromas and trametinib in combination with dabrafenib in subjects with cancers harboring V600 mutations, Vol. 2016. Available at: https://clinicaltrials.gov/ct2/show/NCT02124772.

Kadonaga JN, Barkovich AJ, Edwards MS, Frieden IJ (1992) Neurocutaneous melanosis in association with the Dandy-Walker complex. Pediatr Dermatol 9(1): 37-43.

Kinsler VA, O'Hare P, Bulstrode N, Calonje JE, Chong WK, Hargrave D, Jacques T, Lomas D, Sebire NJ, Slater O (2017a) Melanoma in congenital melanocytic naevi. Br J Dermatol; e-pub ahead of print 12 January 2017; doi:10.1111/bjd.15301.

Kinsler VA, Polubothu S, Calonje JE, Chong WK, Thompson D, Jacques T, Morrogh D (2017b) Copy number abnormalities in new or progressive 'neurocutaneous melanosis' confirm it as primary CNS melanoma. Acta Neuropathol 133(2): 329-331.

Kinsler V, Shaw AC, Merks JH, Hennekam RC (2012) The face in congenital melanocytic nevus syndrome. Am J Med Genet A 158A(5): 1014-1019.

Kinsler VA, Chong WK, Aylett SE, Atherton DJ (2008) Complications of congenital melanocytic naevi in children: analysis of 16 years' experience and clinical practice. Br J Dermatol 159(4): 907-914.
Kinsler VA, Thomas AC, Ishida M, Bulstrode NW, Loughlin S, Hing S, Chalker J, McKenzie K, Abu-Amero S, Slater O, Chanudet E, Palmer R, Morrogh D, Stanier P, Healy E, Sebire NJ, Moore GE (2013) Multiple congenital melanocytic nevi and neurocutaneous melanosis are caused by postzygotic mutations in codon 61 of NRAS. J Invest Dermatol 133(9): 2229-2236.

Krengel S, Hauschild A, Schafer T (2006) Melanoma risk in congenital melanocytic naevi: a systematic review. Br J Dermatol 155(1): 1-8.

Krengel S, Scope A, Dusza SW, Vonthein R, Marghoob AA (2013) New recommendations for the categorization of cutaneous features of congenital melanocytic nevi. J Am Acad Dermatol 68(3): 441-451.

Kusters-Vandevelde HV, Willemsen AE, Groenen PJ, Kusters B, Lammens M, Wesseling P, Djafarihamedani M, Rijntjes J, Delye H, Willemsen MA, van Herpen CM, Blokx WA (2014) Experimental treatment of NRASmutated neurocutaneous melanocytosis with MEK162, a MEK-inhibitor. Acta Neuropathol Commun 2: 41.

Marana Perez AI, Ruiz-Falco Rojas ML, Puertas Martin V, Dominguez Carral J, Carreras Saez I, Duat Rodriguez A, Sanchez Gonzalez V (2016) Analysis of Sturge-Weber syndrome: a retrospective study of multiple associated variables. Neurologia.

Neuhold JC, Friesenhahn J, Gerdes N, Krengel S (2015) Case reports of fatal or metastasizing melanoma in children and adolescents: a systematic analysis of the literature. Pediatr Dermatol 32(1): 13-22.

Pawlikowski JS, Brock C, Chen SC, Al-Olabi L, Nixon C, McGregor F, Paine S, Chanudet E, Lambie W, Holmes WM, Mullin JM, Richmond A, Wu H, Blyth K, King A, Kinsler VA, Adams PD (2015) Acute inhibition of MEK suppresses congenital melanocytic nevus syndrome in a murine model driven by activated NRAS and Wnt signaling. J Invest Dermatol 135(11): 2902.

Pedersen M, Kusters-Vandevelde HV, Viros A, Groenen PJ, Sanchez-Laorden B, Gilhuis JH, van Engen-van Grunsven IA, Renier W, Schieving J, Niculescu-Duvaz I, Springer CJ, Kusters B, Wesseling P, Blokx WA, Marais R (2013) Primary melanoma of the CNS in children is driven by congenital expression of oncogenic NRAS in melanocytes. Cancer Discov 3(4): 458-469.

Salgado CM, Basu D, Nikiforova M, Hamilton RL, Gehris R, Jakacki R, Panigrahy A, Yatsenko S, Reyes-Mugica M (2015) Amplification of mutated NRAS leading to congenital melanoma in neurocutaneous melanocytosis. Melanoma Res 25(5): 453-460.

Sutton BJ, Tatter SB, Stanton CA, Mott RT (2011) Leptomeningeal melanocytosis in an adult male without large congenital nevi: a rare and atypical case of neurocutaneous melanosis. Clin Neuropathol 30(4): 178-182.

Szathmari A, Perbet R, Hermier M, Di Rocco F, Frappaz D, Mottolese C (2016) Primary amelanotic leptomeningeal melanomatosis in a child: a rare but severe disease. World Neurosurg 92: 581.e15-581.e20.

Waelchli R, Aylett SE, Atherton D, Thompson D, Chong WK, Kinsler VA (2015) Classification of neurological abnormalities in children with congenital melanocytic naevus syndrome identifies MRI as the best predictor of clinical outcome. Br J Dermatol 173(3): 739-750.

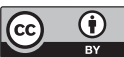

This work is licensed under the Creative Commons Attribution 4.0 International License. To view a copy of this license, visit http://creativecommons.org/licenses/by/4.0/

(C) The Author(s) named above 2017 